\title{
Regular Article \\ Control of contaminants during introduction and establishment of Bambusa vulgaris in vitro
}

\section{Gustavo Rubens de Castro Torres*, Laureen Michelle Houllou, Robson Antônio de Souza}

\author{
Plant Tissue Laboratory, Northwest Strategic Technologies Center (CETENE) \\ Cidade Universitária. CEP 50.740 -540. Recife, Pernambuco, Brazil \\ *Corresponding author E- mail: gustavo.torres@cetene.gov.br
}

The aim of this work was to test techniques to reduce microbial contamination in the phases of introduction and establishment of the in vitro cultivation of Bambusa vulgaris through two experiments. The first experiment was carried out in a completely randomized design using a factorial arrangement (pre-treatment of nodal segments using or not a solution of Derosal $500 \mathrm{SC}^{\circledR}$ and Chloramphenicol $\times$ culture medium with half or full concentration of salts $\times$ culture medium with presence or absence of sucrose $\times$ culture medium with presence or absence of Plant Preservative Mixture ${ }^{\mathrm{TM}}$ ). In a second experiment, carried out in a completely randomized design, the effect of different fungicides associated to Chloramphenicol in a liquid culture medium was tested. It was possible to verify that the isolated effects of the pre-treatment by immersion of the nodal segments in a solution of $4 \mathrm{~mL} \mathrm{~L}^{-1}$ of Derosal $500 \mathrm{SC}^{\circledR}$ and $200 \mathrm{mg} \mathrm{L}^{-1}$ of Chloramphenicol for 30 minutes and explants placed in a sucrose-free medium reduced fungal contamination. In the second experiment, the treatment that reduced fungal contamination corresponded to explants placed for seven days in a liquid medium with half the concentration of salts, sucrose-free, with $2 \mathrm{~mL} \mathrm{~L}^{-1}$ of Plant Preservative Mixture and with $4 \mathrm{~mL} \mathrm{~L}^{-1}$ of Derosal $500 \mathrm{SC}^{\circledR}$ and $200 \mathrm{mg} \mathrm{L}^{-1}$ of Chloramphenicol.

Keywords: Micropropagation, Bamboo, Contamination.

Bamboo is a member of the Poaceae family with fast growth and multiple uses of high economic and environmental value (Lin et al., 2012). Brazil is the country of the New World with the greatest diversity of species (Manhães, 2008), where the incentive to different uses of bamboo increased after the Law n. 12.484, of September 08, 2011, which instituted the National Policy of Incentive to the Sustainable Handling and Cultivation of Bamboo - PNMCB (Generoso, 2014).

Fast propagation of bamboo through vegetative methods to establish commercial fields is not simple, but techniques of in vitro micropropagation have the potential to meet the demand of seedlings. However, microbial contamination is an important limiting factor (Generoso, 2014) because the growth medium in which the plant tissue is cultivated is also a good source of nutrients for microbial growth (Msgoya et al., 2012).

Different works concerning to in vitro micropropagation of bamboo species report the control of contaminations by disinfecting explants using ethanol, sodium hypochlorite and mercuric chloride solutions, isolated or combined, in different concentrations and time intervals (Anand et al., 2013; Jha, et al., 2013; Sharma and Sarma, 
2013; Wadaktar et al., 2014). There are also reports of disinfection using the referred products associated to the pre-treatment of explants by immersion in short time intervals in Bavistin ${ }^{\circledR}$, Streptocyclin and Rifampicin (Ali et al., 2009), Bavistin ${ }^{\circledR}$ and Streptomycin (Arya and Arya, 2009) and MANCOZEBE ${ }^{\circledR}$ and Gentamicin (Mudoi et al., 2014).

Symbiotic epiphytic and endophytic microorganisms or parasites cause the contamination of in vitro micropropagation process, and the use of anti-microbial products of superficial action does not guarantee the obtainment of material free of microbial contaminants. The aim of this work was to test the efficiency of different techniques to introduce and establish Bambusa vulgaris Schrad. ex J.C. Wendl nodal segments in vitro free of microorganisms contaminants.

\section{Material and Methods}

This study was based on two experiments carried out from August to October 2014 at the Laboratory of Applied Researches to Biofactory (LAPAB), in the Northeast Strategic Technologies Center CETENE, Recife, Brazil.

Experiment 01 - Pre-treatment of nodal segments in Derosal $500 \mathrm{SC}^{\circledR}$ and Chloramphenicol and components from the culture medium.

Nodal segments were collected in August 2014 in Recife ( $8^{\circ} 32^{\prime} 26.16^{\prime \prime} S$ and $\left.34^{\circ} 58^{\prime} 27.56^{\prime \prime} \mathrm{W}\right)$ from primary branches in the middle portion of one year old culms of $B$. vulgaris with swollen buds and no sprouts in mother clumps were about 40 years old at the property of Francisco Brennand, in the neighborhood of Várzea, city of Recife-PE ( $8^{\circ} 32^{\prime}$ 26.16" south latitude and $34^{\circ} 58^{\prime} 27.56^{\prime \prime}$ west longitude).

The leaves sheaths covering the buds were removed manually and the branches were washed in tap water with commercial neutral detergent and sectioned into nodal segments of $4 \mathrm{~cm}$ obtained from the interval between the fourth and eighth bud, counted from the apex to the base of the branch. The diameter of 20 segments was measured with a caliper $1 \mathrm{~cm}$ below the leaf scar. The explants presented average diameter of $3,97 \pm 0,98 \mathrm{~mm}$.

The nodal segments (explants) were immersed in $1 \%$ benzalkonium chloride solution for 10 minutes under agitation, rinsed once in non-sterile distilled water for 1 minute and divided into two groups, which were subjected to two different pretreatments, separately: a) immersion for 30 minutes under agitation in solution of $4 \mathrm{~mL}$ $\mathrm{L}^{-1}$ of Derosal $500 \quad \mathrm{SC}^{\circledR}$ (Concentrated Suspension of CARBENDAZIM $500 \mathrm{~g} \mathrm{~L}^{-1}$, Bayer S/A) and $200 \mathrm{mg} \mathrm{L}^{-1}$ of Chloramphenicol and; b) immersion in distilled water (without Derosal 500 SC ${ }^{\circledR}$ and Chloramphenicol). After that, all the explants were rinsed once in non-sterile distilled water for 1 minute.

The explants were manipulated in a laminar flow cabinet where disinfection was conducted with immersion in $70 \%$ ethanol solution for 3 minutes; immersion in $1 \%$ sodium hypochlorite solution for 10 minutes; one wash in sterile water for 1 minute; immersion in $1 \%$ of sodium hypochlorite for 10 minutes; and three consecutive washes in sterile distilled water for 1 minute each. The explants had the basal end trimmed in $2 \mathrm{~mm}$ and placed vertically in test tubes with different culture mediums.

The experiment was carried out in a completely randomized design in a $2 \times 2 \times 2 \times 2$ factorial arrangement corresponding to the combinations: pretreatment with or without immersion in Derosal $500 \mathrm{SC}^{\circledR}$ and Chloramphenicol $\times$ deposition of the explants in a MS (Murashige and Skoog, 1962) semi-solid medium with half or full concentration of salts $\times$ MS medium with or without sucrose $\times$ MS medium with or without PPM (Plant Preservative Mixture ${ }^{\mathrm{TM}}$, Plant Cell Technology) (Table 1). Each treatment had five replicates composed by three test tubes containing one explant in $10 \mathrm{~mL}$ of $\mathrm{MS}$ semi-solid medium. In all treatments the MS medium contained $0.5 \mathrm{mg} \mathrm{L}^{-1}$ of 6benzylaminopurine (BAP). 
The tubes were kept in a growth room under at $24 \pm 2^{\circ} \mathrm{C}$ and photoperiod of 16 hours.

The evaluations of fungal contamination and sprouting were performed 14 days after the release of the experiment and data were subjected to the analysis of variance, and the averages compared according to the Duncan Test at $5 \%$ of probability.

Table 1. Code and description of the treatments of the experiment 1

\begin{tabular}{|c|c|c|}
\hline \multirow{2}{*}{ Treatment } & \multicolumn{2}{|r|}{ Description } \\
\hline & Pre-treatment & *MS semi-solid medium \\
\hline IA1 & \multirow{8}{*}{$\begin{array}{l}\text { with }{ }^{* *} \text { Derosal } 500 \\
\text { SC }{ }^{\circledR}\left(4 \mathrm{~mL} \mathrm{~L}^{-1}\right) \text { and } \\
\text { Chloramphenicol } \\
\left(200 \mathrm{mg} \mathrm{L}^{-1}\right)\end{array}$} & half concentration of salts, with sucrose and with ${ }^{* * * P P M}$ \\
\hline IA2 & & half concentration of salts, with sucrose and with no PPM \\
\hline IB1 & & half concentration of salts, with no sucrose and with PPM \\
\hline IB2 & & half concentration of salts, with no sucrose and no PPM \\
\hline IC1 & & full concentration of salts, with sucrose and with PPM \\
\hline IC2 & & full concentration of salts, with sucrose and with no PPM \\
\hline ID1 & & full concentration of salts, with no sucrose and with PPM \\
\hline ID2 & & full concentration of salts, with no sucrose and no PPM \\
\hline IIA1 & \multirow{8}{*}{$\begin{array}{l}\text { without }{ }^{* *} \text { Derosal } \\
500 \mathrm{SC}^{\circledR}\left(4 \mathrm{~mL} \mathrm{~L}^{-1}\right) \\
\text { and } \\
\text { Chloramphenicol } \\
\left(200 \mathrm{mg} \mathrm{L}^{-1}\right)\end{array}$} & half concentration of salts, with sucrose and with ***PPM \\
\hline IIA2 & & half concentration of salts, with sucrose and with no PPM \\
\hline IIB1 & & half concentration of salts, with no sucrose and with PPM \\
\hline IIB2 & & half concentration of salts, with no sucrose and no PPM \\
\hline IIC1 & & full concentration of salts, with sucrose and with PPM \\
\hline IIC2 & & full concentration of salts, with sucrose and with no PPM \\
\hline IID1 & & full concentration of salts, with no sucrose and with PPM \\
\hline IID2 & & oncentration of salts, with no sucrose and no PPM \\
\hline
\end{tabular}

*MS semi-solid medium = medium described by Murashige and Skoog (1962); ** Derosal 500 $\mathrm{SC}^{\circledR}=$ Concentrated suspension of CARBENDAZIM $500 \mathrm{~g} \mathrm{~L}^{-1}$, Bayer S/A; ${ }^{* * * P P M}=$ Plant Preservative Mixture ${ }^{\mathrm{TM}}$.

Experiment 02 - Fungicides and antibiotics added to the culture medium.

Primary branches were collected in September 2014, from the same mother bamboo clumps in the field and following the same procedures for collecting, washing, obtaining the nodal segments and disinfestation described in the previous experiment. The explants presented average diameter of $4,24 \mathrm{~mm}( \pm 1.07)$, which is close to the value found in the previous experiment demonstrating similarity in the standard of development of the branches used as nodal segments donor in both experiments. 
All the explants were subjected to the pre-treatment of immersion in solution of Derosal $500 \quad \mathrm{SC}^{\circledR} \quad\left(4 \quad \mathrm{~mL}^{\circledR} \quad \mathrm{L}^{-1}\right)$ and Chloramphenicol (200 mg L $\left.\mathrm{L}^{-1}\right)$ for 30 minutes under agitation.

The explants were introduced in flasks containing $20 \mathrm{~mL}$ of a MS liquid medium with half of the concentration of salts described by Murashige and Skoog (1962), no sucrose, with PPM (2 mL L-1), with $\operatorname{BAP}\left(0,5 \mathrm{mg} \mathrm{L}^{-1}\right)$ and with different fungicides associated to the antibiotic Chloramphenicol, except Kasumin ${ }^{\circledR}$ (Soluble Concentrated of KASUGAMYCIN $20 \mathrm{~g} \mathrm{~L}^{-1}$, Arysta Lifescience do Brasil Indústria Química e Agropecuária Ltda), composing the following treatments: Treatment I - medium with Derosal 500 SC ${ }^{\circledR}\left(4 \mathrm{~mL} \mathrm{~L}^{-1}\right)$ and Chloramphenicol (200 $\left.\mathrm{mg} \mathrm{L}^{-1}\right)$; Treatment II - medium with Tairel Plus $^{\circledR} \quad$ (BENALAXYL $80 \quad \mathrm{~g}^{\mathrm{kg}} \mathrm{kg}^{-1}$ and CHLORATHALONIL $400 \mathrm{~g} \mathrm{~kg}^{-1}$ wettable powder formulation, Arysta Lifescience do Brasil Indústria Química e Agropecuária Ltda) (5 $\left.\mathrm{g} \mathrm{L}^{-1}\right)$ and Chloramphenicol (200 mg L-1); Treatment III - medium with Kasumin $^{\circledR}$ (3 $\left.\mathrm{mL} \mathrm{L}^{-1}\right)$; Treatment IV medium with Cetoconazol ${ }^{\circledR}\left(200 \mathrm{mg} \mathrm{L}^{-1}\right)$ (tablet of KETOCONAZOLE, $200 \mathrm{mg}$, Medley) and Chloramphenicol (200 mg L-1) and; Treatment $\mathrm{V}$ - medium without fungicide or antibiotic. The experiment was carried out in a completely randomized design with five treatments, with five replicates constituted by five flasks containing one explant in the mediums described for each treatment. The flasks were kept in a growth room at $24 \pm 2^{\circ} \mathrm{C}$ and photoperiod of 16 hours.

The explants were transferred to tubes containing $10 \mathrm{~mL}$ of MS semi-solid medium with the full concentration of salts, with sucrose, with BAP $\left(0.5 \mathrm{mg} \mathrm{L}^{-1}\right)$ and with PPM (2 mL L-1) seven days after the experiment release. Initially, two evaluations of fungal contamination and sprouting were performed at five and seven days after the experiment release. At the 23th day the fungal and sprouting evaluations were performed, considering the number of: explants with fungal contamination, explants with bacterial contamination, explants with fungal and bacterial contamination, explants with sprouted buds, and healthy and sprouted explants. Data were subjected to the analysis of variance and the averages of the different treatments were subjected to the Duncan test at $5 \%$ probability.

\section{Results}

Experiment 01 - Pre-treatment of explants in Derosal $500 \mathrm{SC}^{\circledR}$ and Chloramphenicol and components of the culture medium to reduce microbial contamination.

Observations of fungal contamination and bud sprouting 14 days after the release of the experiment, showed no significant interaction between the factors: pre-treatment, salt concentrations, sucrose and PPM in the MS medium.

Fungal contamination was significantly higher in treatments which the explants were not immersed in a solution of Derosal $500 \quad \mathrm{SC}^{\circledR} \quad\left(4 \quad \mathrm{~mL} \quad \mathrm{~L}^{-1}\right)$ and Chloramphenicol (200 mg L-1) (Table2). There was no significant difference for the treatments which explants were kept in a MS medium with half or full concentration of salts. Fungal contamination was significantly higher in the treatments with sucrose in the medium (99\%) when compared to those with no sucrose $(67.3 \%)$ but showed no difference regarding the presence or absence of PPM in the MS medium (Table 2).

The bud sprouting was not significantly different when comparing the averages of the treatments regarding the type of pre-treatment, however, it was significantly higher in the treatments with MS medium containing half of the concentration of salts (93\%) compared to those with the full concentration of salts $(83.6 \%)$ (Table2).

The presence of sucrose in the medium positively influenced bud sprouting $(95.7 \%)$ when compared to those with no sucrose $(81 \%)$. Explants cultivated with PPM showed significantly more bud sprouting (94\%) then in the absence of PPM (83\%) (Table 2). 
Table 2. Average number and percentage of explants with fungal contamination and with sprouted buds in different treatments 14 days after the experiment 1 release.

\begin{tabular}{|c|c|c|c|c|c|}
\hline \multirow{2}{*}{ Factor } & \multirow{2}{*}{ Description } & \multicolumn{2}{|c|}{ aFungal contamination } & \multicolumn{2}{|c|}{ bSprouting } \\
\hline & & Average & $\%$ & Average & $\%$ \\
\hline \multirow{3}{*}{ Pre-treatment } & $\begin{array}{l}\text { With Derosal } 500 \mathrm{SC}^{\circledR} \text { and } \\
\text { Chloramphenicol }\end{array}$ & *2.33 b & 77.7 & *2.74 a & 91.3 \\
\hline & $\begin{array}{l}\text { With no Derosal } 500 \mathrm{SC}^{\circledR} \text { or } \\
\text { Chloramphenical }\end{array}$ & $2.66 \mathrm{a}$ & 88.7 & $2.56 \mathrm{a}$ & 85.3 \\
\hline & cC.V. & 7.259 & & 7.575 & \\
\hline \multirow{3}{*}{$\begin{array}{l}\text { Concentration of } \\
\text { salts in the } \\
\text { medium }\end{array}$} & Full & $2.46 \mathrm{a}$ & 82.0 & $2.51 \mathrm{~b}$ & 83.6 \\
\hline & Half & $2.54 \mathrm{a}$ & 84.7 & $2.79 \mathrm{a}$ & 93.0 \\
\hline & C.V. & 4.990 & & 4.968 & \\
\hline \multirow{3}{*}{$\begin{array}{l}\text { Sucrose in the } \\
\text { medium }\end{array}$} & Present & $2.97 \mathrm{a}$ & 99.0 & $2.87 \mathrm{a}$ & 95.7 \\
\hline & Absent & $2.02 \mathrm{~b}$ & 67.3 & $2.43 \mathrm{~b}$ & 81.0 \\
\hline & C.V. & 6.802 & & 6.881 & \\
\hline \multirow{3}{*}{$\begin{array}{l}\text { PPM in the } \\
\text { medium }\end{array}$} & Present & $2.44 \mathrm{a}$ & 81.3 & $2.49 \mathrm{~b}$ & 83.0 \\
\hline & Absent & $2.56 \mathrm{a}$ & 85.3 & $2.82 \mathrm{a}$ & 94.0 \\
\hline & C.V. & 11.002 & & 10.929 & \\
\hline
\end{tabular}

*Averages transformed in $\sqrt{ } \mathrm{x}+1$ for analysis, presenting the original averages that accompanied by the same letter regarding the treatments of each factor alone do not significantly differ by the Duncan Test. aFungal Contamination $=$ explants with fungal contamination; ${ }^{b}$ Sprouting $=$ explants with sprouted buds; ${ }^{c}$ C.V. $=$ Coefficient of Variation.

Experiment 2 - Evaluation of the efficiency of different fungicides and antibiotics added to the culture medium to reduce microbial contamination.

Fungal contamination at five days was significantly higher in the treatments with no fungicide or antibiotic in the medium $(50.4 \%)$ and in the medium with Kasumim $^{\circledR} \quad\left(3 \quad \mathrm{~mL}^{-1}\right) \quad(37.2 \%)$ when compared to the other treatments (no contamination). Sprouting at five days was not significantly different among the treatments (Table 3).

Fungal contamination at seven days was also significantly higher in the treatments with no fungicide or antibiotic $(91.8 \%)$ and in the medium with Kasumim ${ }^{\circledR}$
(3 mL L-1) (57.6\%) when compared to the others. At this time was possible to observe an increase in the average number of contaminated explants in the treatments with Kasumim ${ }^{\circledR}\left(3 \mathrm{~mL} \mathrm{~L}^{-1}\right)$, Cetoconazol ${ }^{\circledR}$ (200 $\mathrm{mg} \mathrm{L}^{-1}$ ) and Chloramphenicol (200 mg $\left.\mathrm{L}^{-1}\right)$ and medium with no fungicide or antibiotic. The treatments with Derosal 500 $\mathrm{SC}^{\circledR}\left(4 \mathrm{~mL} \mathrm{~L}^{-1}\right)$ and Chloramphenicol (200 mg L-1) and with Tairel Plus ${ }^{\circledR}\left(5 \mathrm{~g} \mathrm{~L}^{-1}\right)$ and Chloramphenicol (200 $\left.\mathrm{mg} \mathrm{L}^{-1}\right)$ did not present any fungal contamination in both evaluations.

Average sprouting was the same at five and seven days and remain the same until the end of the experiment showing no differences among treatments (Table 3 ). 
Table 3. Average and percentage of explants with sprouted buds and explants with fungal contamination at five and seven days after the release of experiment 2

\begin{tabular}{|c|c|c|c|c|c|c|c|c|}
\hline \multirow{3}{*}{ Treatments } & \multicolumn{4}{|c|}{ Evaluation at 5 days } & \multicolumn{4}{|c|}{ Evaluation at 7 days } \\
\hline & \multicolumn{2}{|c|}{ aSprouting } & \multicolumn{2}{|c|}{ bContamination } & \multicolumn{2}{|c|}{ aSprouting } & \multicolumn{2}{|c|}{ bContamination } \\
\hline & Average & $\%$ & Average & $\mathrm{d} \%$ & Average & $\%$ & Average & $\%$ \\
\hline $\begin{array}{l}\text { Medium with Derosal } \\
500 \mathrm{SC}^{\circledR}\left(4 \mathrm{~mL} \mathrm{~L}^{-1}\right) \\
+ \text { Chloramphenicol } \\
\left(200 \mathrm{mg} \mathrm{L}^{-1}\right)\end{array}$ & *2.32 a & 46.4 & $0 \mathrm{~b}$ & 0 & $2.32 \mathrm{a}$ & 46.4 & $0 \mathrm{~b}$ & 0 \\
\hline $\begin{array}{l}\text { Medium with Tairel } \\
\text { Plus }^{\circledR}\left(5 \mathrm{~g} \mathrm{~L}^{-1}\right)+ \\
\text { Chloramphenicol }^{-}(200 \\
\left.\text { mg L-1 }^{-1}\right)\end{array}$ & $2.56 \mathrm{a}$ & 51.2 & $0 \mathrm{~b}$ & 0 & $2.56 \mathrm{a}$ & 51.2 & $0 \mathrm{~b}$ & 0 \\
\hline $\begin{array}{c}\text { Medium with } \\
\text { Kasumim }^{\circledR}\left(3 \mathrm{~mL}^{-1}\right)\end{array}$ & $3.54 \mathrm{a}$ & 70.8 & $1.86 \mathrm{a}$ & 37.2 & $3.54 \mathrm{a}$ & 70.8 & $2.88 \mathrm{a}$ & 57.6 \\
\hline $\begin{array}{c}\text { Medium with } \\
\text { Cetoconazol }^{\circledR}(200 \mathrm{mg} \\
\left.\mathrm{L}^{-1}\right)^{+} \\
\text {Chloramphenicol }(200 \\
\left.\mathrm{mg} \mathrm{L}^{-1}\right)\end{array}$ & $2.50 \mathrm{a}$ & 50 & $0 \mathrm{~b}$ & 0 & $2.50 \mathrm{a}$ & 50 & $0.43 \mathrm{~b}$ & 8.6 \\
\hline $\begin{array}{l}\text { Medium with no } \\
\text { Fungicide and no } \\
\text { Antibiotic }\end{array}$ & $3.34 \mathrm{a}$ & 66.8 & $2.5 \mathrm{a}$ & 50.4 & $3.34 \mathrm{a}$ & 66.8 & $4.59 \mathrm{a}$ & 91.8 \\
\hline${ }^{c} \mathrm{C} . \mathrm{V}$. & 17.573 & & 14.887 & & 17.573 & & 17.502 & \\
\hline
\end{tabular}

*Averages transformed in $\sqrt{ } \mathrm{x}+1$ for analysis, presenting the original values that accompanied by the same letter in the same column do not significantly differ by the Duncan Test. aSprouting = explants with sprouted bud; ${ }^{\mathrm{b} C o n t a m i n a t i o n}=$ explants with fungal contamination. ${ }^{\mathrm{C}} \mathrm{C} . \mathrm{V} . \mathrm{=}$ Coefficient of Variation.

After the period of 23 days the unique treatment with healthy explants that allow new shoots be harvested and transferred to the multiplication phase was MS medium with Derosal $500 \mathrm{SC}^{\circledR}(4 \mathrm{~mL} \mathrm{~L}$ 1) and Chloramphenicol $\left(200 \mathrm{mg} \mathrm{L}^{-1}\right)$. All the others treatments had the explants discarded because of fungal and/or bacterial contamination or because of absent bud sprouting (Table 4). It was possible to observe that, even in the treatment with Derosal $500 \mathrm{SC}^{\circledR}\left(4 \mathrm{~mL} \mathrm{~L}^{-1}\right)$ and Chloramphenicol (200 mg L-1) showed fungal contamination $(12 \%)$ although it was significantly lower when compared to the others (Table 4) and still, it presented bacterial contamination corresponding to $8 \%$.

The average number of explants contaminated by bacteria was low, varying from $0 \%$ to $16 \%$, but with no difference between treatments. Contaminations caused by both fungus and bacteria were also low and did not exceed the percentages mentioned above (Table 4).

Sprouting varied among treatments from $80 \%$ to $96 \%$ with no significant differences, which demonstrated there was not interference of the different products 
and doses tested in the experiments (Table $4)$.

The average number of healthy and sprouted explants differed from the treatments, being significantly higher on those corresponding to the medium with
Derosal $\left(4 \mathrm{~mL} \mathrm{~L}^{-1}\right)+$ Chloramphenicol $(200$ $\mathrm{mg} \mathrm{L}^{-1}$ ) for seven days. It resulted in $68 \%$ of the healthy and sprouted explants, which shoots could be extracted and destined to the phase of multiplication (Table 4).

Table 4 Average number or explants with fungal contamination, bacterial contamination, fungal and bacterial contamination, sprouted bud and healthy and sprouted explants 23 days after the release of experiment 2

\begin{tabular}{|c|c|c|c|c|c|}
\hline Treatments & aFungal & bBacterial & $\begin{array}{l}\text { cFungal } \\
\text { and } \\
\text { Bacterial }\end{array}$ & dSprouting & $\begin{array}{l}\text { eHealthy and } \\
\text { sprouted } \\
\text { explants }\end{array}$ \\
\hline $\begin{array}{l}\text { Medium with Derosal }\left(4 \mathrm{~mL} \mathrm{~L}^{-}\right. \\
\left.{ }^{1}\right)+ \text { Chloramphenicol }(200 \mathrm{mg} \\
\left.\mathrm{L}^{-1}\right)\end{array}$ & ${ }^{*} 0.6 \mathrm{~b}$ & $0.4 \mathrm{a}$ & $0 \mathrm{a}$ & $4.4 \mathrm{a}$ & $3.4 \mathrm{~b}$ \\
\hline $\begin{array}{l}\text { Medium with Tairel Plus ( } 5 \mathrm{~g} \\
\left.\mathrm{~L}^{-1}\right)+ \text { Chloramphenical }(200 \\
\left.\mathrm{mg} \mathrm{L}^{-1}\right)\end{array}$ & $4.8 \mathrm{a}$ & $0.8 \mathrm{a}$ & $0.8 \mathrm{a}$ & $4.4 \mathrm{a}$ & $0 \mathrm{a}$ \\
\hline $\begin{array}{c}\text { Medium with Kasumim (3 mL } \\
\left.\qquad \mathrm{L}^{-1}\right)\end{array}$ & $5.0 \mathrm{a}$ & $0 \mathrm{a}$ & $0 \mathrm{a}$ & $4.8 \mathrm{a}$ & $0.2 \mathrm{a}$ \\
\hline $\begin{array}{l}\text { Medium with Cetoconazol } \\
\quad\left(200 \mathrm{mg} \mathrm{L}^{-1}\right)+ \\
\text { Chloramphenicol }\left(200 \mathrm{mg} \mathrm{L}^{-1}\right)\end{array}$ & $5.0 \mathrm{a}$ & $0.6 \mathrm{a}$ & $0.6 \mathrm{a}$ & $4.6 \mathrm{a}$ & $0 \mathrm{a}$ \\
\hline $\begin{array}{c}\text { Medium with no Fungicide or } \\
\text { Antibiotic }\end{array}$ & $5.0 \mathrm{a}$ & $0 \mathrm{a}$ & $0 \mathrm{a}$ & $4.0 \mathrm{a}$ & $0 \mathrm{a}$ \\
\hline${ }^{\mathrm{f} C . V}$. & 5.002 & 23.483 & 22.369 & 7.090 & 5.549 \\
\hline
\end{tabular}

*Averages transformed in $\sqrt{ } \mathrm{x}+1$ for analysis, presenting the original values that accompanied by the same letter in the same column do not significantly differ from the $5 \%$ error level by the Duncan Test. ${ }^{a}$ Fungal $=$ average number of explants with fungal contamination; ${ }^{b}$ Bacterial $=$ average number of explants with bacterial contamination; cFungal and Bacterial $=$ average number of explants with both contaminations (fungal and bacterial); dSprouting = average number of explants with sprouted bud; eHealthy and Sprouted Explants = average number of healthy and sprouted explants destined to the bud extraction for the phase of multiplication; ${ }^{\mathrm{f} C} . \mathrm{V} .=$ Coefficient of Variation.

\section{Discussion}

The percentages of fungal contamination in the experiment 1 vary from $81.3 \%$ to $99 \%$ in the different factors analyzed and exceeded what Generoso (2014) found for B. vulgaris (60\%), which is justified by what several authors report: the season with more rain events and high humidity interferes on the fungal contamination rate of the bamboo tissues, resulting in elevated percentages (Saxena and Bhojwani, 1993; Ramanayake and Yakandawala, 1997; Sayanika and Sharma, 2009; Anand et al., 2013; Mudoi et al., 2014).
The experiment was carried out in August just after the rainy season in Recife, Brazil (Pfaltzgraff, 2003).

Two isolated factors were responsible for reducing the fungal contamination in the experiment 1 . The first corresponded to the pre-treatment by immersion of the explants in a solution of Derosal $500 \quad \mathrm{SC}^{\circledR} \quad\left(4 \mathrm{~mL}^{\mathrm{L}} \mathrm{L}^{-1}\right)$ and Chloramphenicol (200 mg L-1) for 30 minutes. These treatments resulted in a significantly lower contamination $(77.7 \%)$ when compared to those with no immersion (88.7\%). Jiménez et al. (2006) 
when associating Extran at $0.05 \%$ with Agrimycin ${ }^{\circledR}$ (bactericide) and Benomy ${ }^{\circledR}$ at 2

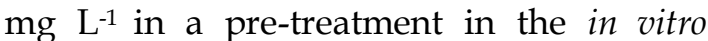
micropropagation, with disinfection of explants in a $1 \%$ sodium hypochlorite for 10 minutes, reached a percentage of contamination of $76 \%$, which was close to the obtained in the experiment $1(77.7 \%)$.

The second factor that helped to reduce fungal contamination in the experiment 1 was the absence of sucrose in the MS medium. Treatments which media did not contain sucrose presented a significantly lower average number of contaminated explants $(67.3 \%)$ when compared to those with sucrose (99\%). Therefore, not adding sucrose to the medium resulted in $32.7 \%$ of clean explants. This result could be considered superior to those reached in the in vitro micropropagation of Dendrocalamus strictus (Roxb.) Nees by Pandley and Singh (2012) by disinfecting explants in a $0.2 \%$ mercuric chloride for 10 minutes $(30 \%)$ and with calcium chloride for 10 minutes (13.13\%), 15 minutes $(23.33 \%)$ and 20 minutes $(26.67 \%)$, that is, the suppression of a component (sucrose) of the medium guaranteed a percentage of sanity higher than to that reached by using products for disinfection.

The fact that fungal contamination did not differ significantly among the treatments with or without PPM agreed with the results of Jiménez et al. (2006) in the micropropagation in vitro of Guadua angustifolia Kunth. By including the product in the MS medium, the authors did not have a satisfactory control of the contaminations in explants from donors clumps kept in a field, unlike those kept in greenhouses and subjected to the application of the fungicide Benomyl ${ }^{\circledR}$.

The high percentage of sprouting reached in the experiment 1 by using from fourth to eighth buds of the primary branch to obtain the nodal segments are according to the percentage obtained by Sayanika and Sharma (2009) by using the central buds of the branches of Arundinaria callosa Munro when compared to the buds of the apex and the base. Also like Mudoi et al. (2014) by proving that buds located between the fourth and seventh position in the branches guaranteed highest percentage of sprouting for Bambusa nutans Wall ex. Munro.

Despite to the elevated levels of contamination found in experiment 1 , the different factors evaluated did not result in low percentages of sprouting, which varied from $81 \%$ to $95.7 \%$, an interval superior to those obtained by Sayanika and Sharma (2009) for Arundinaria callosa Munro (from $34 \%$ to $66 \%$ ), Pandey and Singh (2012) for D. strictus (from $6.67 \%$ to $30 \%$ ), and by Generoso (2014) for B. vulgaris (80\%).

The fungal contamination of $12 \%$ observed in the experiment 2 with MS liquid medium with Derosal 500 SC ${ }^{\circledR}(4 \mathrm{~mL}$ $\mathrm{L}^{-1}$ ) and Chloramphenicol (200 mg L-1) for seven days was lower than $52 \%$ found by Jiménez et al. (2006) during in vitro micropropagation of $G$. angustifolia in the pre-treatment with Extran plus Agrimycin $^{\circledR}$ and Benomyl ${ }^{\circledR}$ associated to the disinfection using sodium hypochlorite solution. It was also lower than $36 \%$ and $48 \%$ obtained by Generoso (2014), when he tested media containing or not sodium hypochlorite, respectively.

The treatment with MS liquid medium with Derosal $500 \mathrm{SC}^{\circledR}\left(4 \mathrm{~mL} \mathrm{~L}^{-1}\right)$ and Chloramphenicol (200 mg L-1) for seven days was also promising regarding the percentage of healthy and sprouted explants $(68 \%)$, which was close to the results found by Pandey and Singh (2012) by testing $0.2 \%$ mercuric chloride for 10 minutes and 15 minutes in the pretreatment of explants of D. strictus and found $66.67 \%$ and $69.23 \%$, respectively. The treatment also overcame those obtained by Ramanyake et al. (2006) in vitro micropropagation of Bambusa vulgaris 'Striata' (Lodd. ex Lindl.) Gamble when added Benlate ${ }^{\circledR}$ at $0.1 \%$ to the MS medium for bud sprouting. The author reports that only $50 \%$ of the explants sprouted and $15 \%$ were contaminant-free. In the treatment with MS liquid medium plus Derosal 500 $\mathrm{SC}^{\circledR}\left(4 \mathrm{~mL} \mathrm{~L}^{-1}\right)$ and Chloramphenicol (200 $\mathrm{mg} \mathrm{L}^{-1}$ ) for seven days, the percentage of 
sprouting was $88 \%$ and fungal contamination, $12 \%$.

The pre-treatment of explants using solutions containing CARBENDAZIMbased antibiotics and fungicide, active ingredient of Derosal $500 \mathrm{SC}^{\circledR}\left(4 \mathrm{~mL} \mathrm{~L}^{-1}\right)$, is quoted in works about in vitro cultivation of Bambusa balcooa Roxb. (Sharma and Sarma, 2011), Dendrocalamus hamiltonii Munro (Jha et al., 2013) and Bambusa tulda Roxb. (Sharma and Sarma, 2013), conducting a 15minute immersion in an aqueous solution at $0.5 \%$ of the commercial product and Bambusa bambos (L.) Voss in a $0.1 \%$ solution of the commercial product (Anand et al., 2013). However, in none of the works the product was added in the culture medium.

The high percentage of sprouting obtained in all the treatments of the experiment 2, varying from $80 \%$ to $96 \%$, confirms the results obtained in the experiment 1 and corroborates the results found in Sayanika and Sharma (2009) regarding A. Callosa and Mudoi (2014) for B. nutans, who found more elevated percentages by using the buds that hold the central position of the primary branch.

\section{Conclusion}

The pre-treatment of the explants through immersion in a solution of Derosal $500 \mathrm{SC}^{\circledR}\left(4 \mathrm{~mL} \mathrm{~L}^{-1}\right)$ and Chloramphenicol (200 mg L-1) for 30 minutes placed in a MS liquid medium with half of the concentration of salts, sucrose-free, with PPM (2 mL L-1), with Derosal 500 SC $^{\circledR}(4 \mathrm{~mL}$ $\left.\mathrm{L}^{-1}\right)$ and Chloramphenicol (200 $\left.\mathrm{mg} \mathrm{L}^{-1}\right)$ for seven days demonstrated to be effective to control microbial contaminations of in vitro micropropagation of $B$. vulgaris, guaranteeing a higher percentage of healthy and sprouted explants, which shoots can be used in the phase of multiplication.

\section{Acknowledgements}

The authors thank to Ministry of Science, Technology and Innovation and The National Counsel of Technological and Scientific Development for financial support.

\section{References}

ALI AH, NIRMALA, C, BADAL T, SHARMA ML. In vitro Organogenesis and Simultaneous Formations of Shoots and Roots from Callus in Dendrocalamus asper. Horticulture 2009; 6: 31-40

ANAND M, BRAR J, SOOD A. In Vitro Propagation of Edible Bambu Bambusa bambos and Assessment of Clonal Fidelity through Molecular Markers. Journal of Medical and Bioengineering 2013; 2(4): 257-261

ARYA ID, ARYA S. Propagation of Bamboos through Culture Technology and Field Plantation. Horticulture 2009; 6: 131-143

GENEROSO, AL. Caracterização Morfológica e Cultivo in vitro de Espécies de Bambu. Dissertação (Mestrado em Genética e Melhoramento de Plantas) - Centro de Ciências e Tecnologias Agropecuárias, Universidade Estadual Norte Fluminense Darcy Ribeiro, Campos dos Goytacazes-RJ; 2014.

JHA A, DAS S, KUMAR B. Micropropagation of Dendrocalamus hamiltonii through nodal explants. Global Journal of Bio-Science and Biotechonolgy 2013; 2(4): 580-582

JIMÉNEZ, VM, CASTILLO J, TAVARES E, GUEVARA E, MONTIEL M. In vitro propagation of the neotropical giant bamboo. Guadua angustifolia Kunt, trough axillary shoot. Plant Cell Tissue Organ Culture 2006; 86: 389-395

LIN, X.; HUANG, L.; FANG, W. Bamboo regeneration via embryogenesis and organogenesis. In: Sato, Ken-Ichi, editor. Embryogenesis. Rijeka: INTECH; 2012. p. 359-372.

MANHÃES AP. Caracterização da Cadeia Produtiva do Bambu no Brasil: Abordagem Preliminar. Monografia (Bacharelado em Engenharia Florestal) Departamento de Silvicultura, Instituto de Florestas, Universidade Federal do Rio de Janeiro, Seropédica-RJ; 2008.

MSOGOYA T, KANIAGHA H, MUTIGITU $\mathrm{J}$, KULEBELWA M, MAMIRO D. Identification and Management of 
Microbial Contaminants of Banana in vitro Cultures. Journal of Applied Biosciences 2012; 55: 3987-3994

MUDOI KD, SAIKIA SP, BORTHARKHUR M. Effect of nodal positions, seasonal variations, shoot clump and growth regulators on micropropagation of commercially important bamboo, Bambusa nutans Wall. Ex. Muro. African Journal of Biotechnology 2014; 19(19): 1961-1972

MURASHIGE T, SKOOG, F. A revised médium for rapid growth and bioassays with tobacco tissue culture. Physiology Plant 1962; 15: 473-497

PANDEY BN, SINGH, NB. Micropropagation of Dendrocalamus strictus Nees from mature nodal explants. Journal of Applied Natural Science 2012; 4(1): 5-9

PFALTZGRAFF PAS. Sistema de informações geoambientais da Região Metropolitana do Recife. Recife: CPRMServiço Geológico do Brasil; 2003.

SAYANIKA D, SHARMA GJ. In vitro propagation of Arundinaria callosa Munro- an edible bamboo from nodal explants of mature plants. The Open Plant Science Journal 2009; 3: 35-39

SAXENA S. BHOJWANI SS. In vitro clonal multiplication of 4-year-old plants of bamboo, Dendrocalamus longispathus Kurz. In vitro Cell. Dev. Biol. Plant. 1993; 29: 135-142

SHARMA P, SARMA KP. In vitro propagation of Bambusa balcooa for a better environment. In: International Conference on Advances in Biotechnology and Pharmaceutical Sciences. Bangkok: Planetary Scientific Research Centre; 2011 p. 248-252

SHARMA S, SARMA KP. In Vitro Propagation of Bambusa tulda: An Important Plant for Better Environment. Journal of Enviromental Research and Development 2013; 7(3): 1216-1223.

RAMANAYAKE, SMSD, MEEMADUMA VN, WERAWARDENE TE. In vitro shoot proliferation and enhancement of rooting for the large scale propagation of yellow bamboo (Bambusa vulgaris 'Striata'). Sci. Hort. 2006; 110: 109-113

RAMANAYAKE, SMSD, YAKANDAWALA K. Micropropagation of the giant bamboo (Dendrocalamus giganteus Munro) from nodal explants of field grown culms. Plant Sci. 1997; 129: 213-223

WADAKTAR CM, MORE NV, PATIL VV. Initiation of suspension culture and somatic embryogenesis to plant regeneration in multipurpose bamboo (Dendrocalamus tulda). Indian Journal of Applied Research 2014; 4(1): 149-151 